\title{
What Is the Training of the Accounting Professor in Brazil?
}

\author{
Adriana Maria Procópio de Araujo', Roseli Rodrigues de Mello² \\ ${ }^{1}$ Department of Accounting, School of Economics, Business Administration and Accounting, University of São \\ Paulo, Ribeirão Preto, Brazil \\ ${ }^{2}$ Department of Pedagogical Theories and Practices, Federal University of São Carlos, São Carlos, Brazil \\ Email: amprocop@usp.br, roseli@ufscar.br
}

Received 6 February 2014; revised 1 March 2014; accepted 21 March 2014

Copyright (C) 2014 by authors and Scientific Research Publishing Inc.

This work is licensed under the Creative Commons Attribution International License (CC BY). http://creativecommons.org/licenses/by/4.0/

(c) (i) Open Access

\section{Abstract}

The aim of this research is to demonstrate the structure of the Higher Education in Brazil with emphasis in Accounting Education and the college Education of the professor in this field of knowledge. It reports the aspects of college education of the accounting professor from the standpoint of Vasconcelos' model (1994) dividing it into four fields of education: practical training, technicalscientific, pedagogical and, social and political. The gathering of the professors' perceptions was carried out through an online questionnaire. The base of the analysis was in 383 answers, being 307 of the observations considered valid. The results were identified by using descriptive analysis. The research indicates, in this sample, that the accounting sciences professor in Brazil has predominantly a practical training formation lacking pedagogical preparation, which is the highlighted object in this study.

\section{Keywords}

Accounting Education, Professor Training, Higher Education

\section{Introduction}

In Brazil, the researches and studies in the accounting field are mainly directed to studying the problems concerning the technical aspects, among them: (i) a better way to identify the companies' costs; (ii) correct measurement of accounting facts; (iii) analysis of the companies' capital structure and; (iv) influence of the stock market policies in the organizations, etc.

The knowledge acquisition in the several knowledge fields, organized in a systematic and oriented way, forms the human knowledge. Such knowledge is built and accumulated in each phase of the individual's life and several 
are the motivating and propelling factors of this information gathering.

The teaching institution is the place where there is the greatest integration between the knowledge transference and its consolidation, mainly concerning professional, intellectual and social formation of the individual. Several agents are involved in the human knowledge process; among them are: (i) the institution, involving the structure, excellence and management; (ii) teaching staff; (iii) student body; (iv) teaching methods and research; (v) professional recognition; (vi) benefits to the society, and so on.

In the last years, it observed a considerable growth in the articles published in not only national congresses, but also journals with themes related to the teaching and research in controlling and accounting in Brazil. However, it has not been identified yet, in post-graduation programs, consolidated line of research for the field of "accounting education" in Brazil, as it happens in the field of administration.

Among the more than twenty-five post-graduation programs in accounting offered in Brazil, only the program of University of São Paulo, Faculty of Economics, Business Administration and Accounting, presents a specific line of "education and research in accounting".

Each student's learning process depends on at least three components: (i) the student, (ii) the course and, (iii) the professor. Concerning the student, the variables which interfere in this process are his intellectual skills, previous and specific knowledge and his routine and dedication to his studies as well. According to Gil (2006: p. 14), the variables associated to the course, its objectives and organization also influence the learning process since the characteristics of the future professional are defined by the Teaching Institution, through its curriculum, the subject contents and the determination of the teaching strategies.

Concerning the professor, the variables can explain the success or failure in relation to the learning process. The professor must have the domain of the subject and know how to convey such a content in an appropriate and attractive manner to the student, facilitating, therefore, the teaching process.

Worried about both the accounting education in Brazil and the way accounting is taught, this research guided itself for the analysis of the professor training in accounting sciences in Brazil. Besides dominating the subject to be taught, every professor must have the minimum conditions to convey such knowledge. The professor training in accounting sciences does not foresee, in an objective way, the pedagogical training and this deficiency can lead to losses in the teaching and learning process.

In this context, the present study approached the professor training in accounting under the view of professor training model proposed by Vasconcelos (1994) and Vasconcelos (2000) who foresee four groups of professor training: (i) practical training; (ii) technical-scientific training; (iii) pedagogical training and (iv) social and political training. Thus, the perceptions of the professors of the accounting sciences courses in Brazil concerning their own training were analyzed.

The importance of the education process for a country's evolution is notorious. The relation education and development walk together and, somehow, differentiate the peoples and their traits. Therefore, studying the education and the teaching quality contributes for promoting changes and progress of the society. The studies and articles published in the main Scientific Congresses of the field in Brazil (Congresso USP, EnANPAD-EnEPQ and ANPCONT) have focused on the teaching-learning methods, in the quality of the Accounting Sciences courses and in the undergraduate students' performance. Other studies in the field of education focus on the aspects of professor training (Nunes, 2000; Guerra, 2003; Pachane, 2003; Meier, 2004), however, a few studies work specifically on the accounting professor training (Nossa, 1999; Laffin, 2002; Hernandes, 2006; Andere, 2007), making this work scientifically relevant due to the lack of researches with this approach.

The research has social relevance because it contributes for the analysis of the quality of not only education and teaching, but also the training of professionals who work as an indispensable tool for the companies' lives and, therefore, for the market. Thus, from the model presented by Vasconcelos (1994), the question of the research which concentrated the problem was: What is the accounting sciences professor training in Brazil?

The importance of researching the accounting sciences professor training can be grounded in some assumptions: (i) Brazil has presented a growth in the offerings of graduation courses in Accounting Sciences in the last years; (ii) the qualification of the teaching staff; (iii) the influence of the professor in the training of professional, such as, the technical and managerial skills and knowledge for the accounting formation for future managers.

Thus, the main objective of the work was to check the importance given by the professor of accounting sciences courses, in their own training while Higher Education professor of Accounting. The study was directed specifically to the professors of accounting sciences courses in the Higher Education Institutions (HEI) that offer the Accounting Sciences courses in Brazil, who related their perception on their own training, independently of 
their academic formation or specific working area. The focus was the accounting sciences course as a whole.

The specific objectives were detailed in the following way: (i) cataloguing the HEIs that offer the accounting sciences course in Brazil, by building a database of the research; (ii) knowledge of the professor about each catalogued course and respondent; (iii) organization of the information collected from the professor through am e-questionnaire, elaborated according to the model of Vasconcelos (1994) and; (iv) analysis of the sample obtained and surveying of the aspects of professor training.

Due to the growing Accounting course offer in Brazil, professor training becomes important since it directly influences the development of more prepared professional. Thereby, the study of education and teaching of accounting is justified and, besides this prerogative, the professor of this field of accounting sciences acts strongly in other fields of knowledge, mainly in the bachelor professional of Business Administration, Economy, Law as well as Production Engineering.

Some researches related to the theme were explored in Brazil. Among them, we can highlight: Marion (1993) with the study of the accounting teaching aspects in the United States and the parameters of quality of higher Education between Brazil and the US; Nossa (1999), analyzed the causes of deficient training of accounting professors; Cornachione Jr. (2004) studied technology as a tool for the teaching of Accounting Sciences and; Andere (2007) studied the accounting sciences professors' profile by using the master's and doctoral programs in Brazil.

The research presents, besides this introduction, in topic two, the overall picture of education and organization of accounting teaching in Brazil. In section three, an approach on university teaching and in the fourth one, the methodology and sample with the research results are obtained. Finally, the conclusions and the literature are presented.

\section{Education and Higher Education}

Even though the terms education and teaching are known and used very much, it is considered important to define them within the scope of this work. The United Nations Educational, Scientific and Cultural Organization (UNESCO) is a worldwide organization, established in the 1940's and which somehow organizes and maintains the guidelines for worldwide education and teaching, among other activities. From time to time, macro studies are carried out with the purpose of discussing topics related to central education and teaching themes. After the opening of global discussions, UNESCO compiles the official documents, the guidelines. For the worldwide teaching, these guidelines are organized in a 1996 Report $^{1}$. The result of the debates which took place up to that moment and which are still in effect nowadays.

Taking this UNESCO report into account, the central discussion is compiled in four Pillars of Education (Delors, 1999): (i) learning to know; (ii) learning to do; (iii) learning to live together and; (iv) learning to be.

Education is a continuous process and it is present from the time we are born until the end of four existences in the form of information gathering. The formation of each individual is given by the build-up of knowledge each one has, which can, therefore, differentiate them. Thus, it is a socialization and learning process directed to the intellectual and ethical development of an individual. The organized institutions, called "schools", are responsible for the development of this socialization and learning process, calling it education (Martins, 2005).

Furthermore, education is the basis of any society, forming individuals who are more conscious of their roles and the environment they act in, being able to interact "[...] positively in a society, understand it, share ideas, solutions, and discover new ways to interact with the others." By the means of educations, a society can become stronger and fairer, since the roles are played by prepared and motivated individuals, aiming the population welfare (Cornachione Jr., 2004: p. 32).

The school is the central axis of an organized society. Therefore, without going into the conception and formation of elementary and high school education, since it is not the focus of this study, the higher education is within a wide perspective of a political-pedagogical project of a teaching institution. "The political-pedagogical project is seen as a keynote document which gathers the main ideas, fundamentals, curriculum and organizational guidelines of an educational institution or course” (Veiga, 2003: p. 271).

The offering of accounting sciences courses (higher education) in Brazil has grown substantially ${ }^{2}$. Such a fact

\footnotetext{
${ }^{1}$ Report to UNESCOfrom the International Commission on Education for the Twenty-first Century, coordinated by Jacques Delors (1996), available at $<$ http:unesdoc.unesco.org/images/0010/001095/109590por.pdf $>$.

${ }^{2}$ In 2005, there were 846 Higher Education Institutions eligible to offer higher education in Accounting Sciences in Brazil. In 2013, this number had increased to 1200 courses, which means a $40 \%$ increase in 6 years (data of the Instituto Nacional de Estudos e Pesquisas Educacionais Anisio Teixeira_INEP, available at http://sistemascensosuperior.inep.gov.br/censosuperior 2013).
} 
indicates that both the market and the society are appreciating the accounting professional. Linked to the growth, it becomes necessary a follow-up by the Government and by the entities responsible for the professional class, in order to guarantee the quality of these courses. Besides the course's political-pedagogical Project, the concern falls upon the training of the professor who works in this scenario.

\section{University Teaching}

According to Delors (1996: p. 12), "it is the professor's responsibility to convey to the student everything the humanity has learned about itself and the nature, besides whatever essential it has created and invented".

However, it is not just technical responsibility that the professor has to teach. The professor also has the responsibility of forming citizens while professionals who will work in the market. Principles of ethics, citizenship, development of critical analysis to deal with diversities are some of the factors the higher education professor must be prepared to work with. As stated by Mello (1998), when referring to the teaching role: "Thinking about the factors which would compose the complexity frame of teaching, one of great impact would be the confrontation with an infinity of differences which the professor has to live with in a classroom and which he has to learn to deal with. The features overlap the generic student studied in training courses” (Mello, 1998: p. 24).

The role of teaching was constituted, according to Guerra (2003), more from the importance in meeting the supposed needs that appeared along the history than due to the concern in conveying and fulfilling the teaching contents. This role started having meaning and valorization, gradually, according to the context and the moment and it was acquiring its own features and professionalizing.

The professionalization must be stimulated by policies regarding the training of professors, their contracts, the way they give account of their work. As stated by Andere (2007: p. 37), "The professional professor is considered the education manager and his qualification and training have been more and more asked for, along with the review and development of competences and knowledge to follow the information demand and new technologies". Regarding the education quality, certainly, this training, qualification and new competences will have a differential in the final result of the process.

Studying the professor training in a context of intense economic and behavioral changes is essential to improve our positions in the teaching and learning process. The professor is one of the responsible ones for not only the teaching of technical competence to our students, but also the ethical and moral formation of future professional of the market. Living with diversity of students, social positions and economic uncertainties is a professor's task which is not learnt only with training and technical competence. "Learning to be a professor, in this context, is not, therefore, a task which is over after studies of a context apparatus and technique in conveying them. It is a kind of learning that must take place through practical situations which are effectively problematic, which requires the development of a competent reflexive practice. It also requires that, besides knowledge, attitudes are worked on, which are considered important concerning knowledge” (Mizukami et al., 2002: p. 12). Still according to the same authors (p. 13) "professional knowledge is designed as a set of facts, principles, rules and procedures which apply directly to instrumental problems".

Knowing the training of the accounting professor is the aim of this research and it is essential to contribute with researches in the field. In accounting literature, there are not deep researches approaching this theme. The higher education in Accounting Sciences currently represents, the direct insertion of more than 30,000 professionals a year in the market. Working with issues which better prepare this professional is the university's task.

The Statistics of Higher Education disclosed by the Ministry of Education (available at $<$ http://portal.inep.gov.br/superior-censosuperior-sinopse> access 11/15/2003) demonstrates that, in 2012, in Brazil, there were 378,939 professors working with higher education; 118,657 of them, that is, $31.3 \%$ are $\mathrm{PhD}$, post-docs or full professors; 147,876 of the professors are masters and they represent $39 \%$ of the total; $26.4 \%$ are experts (100,138 of them); 3.2\% are graduate, which represents 12,161 professors and less than $1 \%$ are in other conditions (107 of them). Comparing to 5 years, there was significant improvement in the percentage of professor with degrees, mainly in forming PhDs, which increased from $13 \%$ to $31.3 \%$, masters (from $34 \%$ to $39 \%$ ) and the decrease of graduates, which represented $11 \%$ of the total.

The technical and academic degree of the professor is, without any doubts, important requirements for composing the faculty for a certain field of knowledge. It is not, however, the guarantee of success in the teaching and learning process. The most important thing is to have professors qualified for working in the classrooms, with training oriented to the professional qualification and pedagogical knowledge (Feltran, 2002). 
The professor must be prepared to teach and "as as educator and subject of educational process, establish a horizontal relationship with the students seeking the dialog, his entrepreneurial source in the production of knowledge" (Meier, 2004: p. 29). The professor must commit himself and go deeper in the educational themes, going beyond the simple transference of knowledge or professional experiences; he must exercise the guidance, influencing the subject of the education process, the student, to build up his own path, providing a constructive and participative integration between both of them.

One of the ways to ease teaching is analyzing the student beforehand, identifying his profile, his previous performance, and the best way he learns the subject. The knowledge of other methodologies and studies on learning styles is also of great importance for the teacher, due to the fact that if the professors identify their students' characteristics, they will be able to use the most appropriate teaching technique for that target audience (Andere, 2007).

\subsection{Conceptual Guidelines in Professor Training}

The concepts about the professor can vary according to the different approaches, paradigms and guidelines adopted along the history. Many of those concepts are determined by school definitions, teaching and curriculum which are predominant in each time. Currently, the concept of lifelong education has been more and more disseminated and incorporated in the universities. It is documented in the 1996 UNESCO report, as follows: “(...) lifelong learning implies, directly, the concept of 'educational society': in this society multiple learning opportunities are offered, both at school and in the economic, social and cultural life. Therefore, the need to multiply the negotiations and partnerships with families, economic environment, associative world, the actors of cultural life, etc. The teachers are affected, as well, by this imperative of updating knowledge and competences. Their professional life must be organized in such a way that they are able to, even forced to, improve their art and benefit from the experiences lived in several spheres of economic, social and cultural life. In general, such possibilities are foreseen in the multiple forms of leave or sabbatical year; these formulas, properly adapted, must be expanded to all teachers” (Delors, 1996: pp. 34-35).

In the present context, we can observe different images of the professor: efficient, competent, technical, personal, professional, decision maker, investigator, reflexive; several other behavior models: knowledge conveyor, technician, routine performer, decision maker; and several roles to be acted out: manager, expert, apprentice, educator, professor, learner, students' advisor, researcher, evaluator, instructor. These different conception forms of the professor influence in a determining way the content, methods and strategies to train professors (Gómez, 1992; Gil, 2006; Pachane, 2003).

The quality of professor training, according to Guerra (2003: p. 25), can be related to the conceptions on the education professional's role and on the education conception. "Thus, there is the need to assure the intellectual, technical, pedagogical and political competences in professor training”.

In this research, we opted for the competences related to the model of professor training presented by Vasconcelos (1994) which is divided in four aspects: (i) practical training, (ii) technical-scientific training, (iii) pedagogical training and (iv) social and political training.

The study used this model, raised the profile of the higher education liberal-professor professional, such as accountants, administrators, economists, lawyers among other professionals who work as professors in the baccalaureate degree programs in Brazil. The objective of this study was to check the continuing education along with the pedagogical ability. The study also pointed out the reflection of teaching practice and the ideal higher education professor training in the fields mentioned.

\subsubsection{Practical Training}

This training refers to the knowledge of the professional practice under the professor's competence, to provide the student a real and more updated view in order to give meaning to the subject which is being taught implementing, therefore, the learning. Cunha (1996) states that the main strategy used for the explanations of any subject is the building of familiar examples which are close to the students' universe. In this case, this skill is linked to the theory-practice relation the professor has.

It is unquestionable that the professor's experiences and his experience in the field in which his student is being trained in is of fundamental importance in the teaching process, however, the knowledge acquired in this training must be incorporated to the theoretical concepts and the technical-scientific training of the professor so 
that the practical knowledge does not make teaching superficial.

According to Vasconcelos (1994: p. 41) "Relating the theory and practice is a factor of competence guarantee for working in university teaching”. The practical training must be a coadjutant factor to ease the teaching and learning process.

\subsubsection{Technical-Scientific Training}

The technical-scientific training considers that the knowledge of specific subject must be connected to the understanding of the theoretical aspects which relate to the subject. The technical competence must be prerogative of any professor, since his scientific training will be fundamental for building up the knowledge of the student body. The professor must be able to research and get involved in reflexive matters, attend scientific events and university extension courses. According to Vasconcelos (1994: p. 39), “(...) this constant learning by the professor must not crystallize into the passive attitude of the eternal repetition, but it must constitute a solid foundation for new knowledge, new researches, for the scientific investigation in the end”.

The professor with solid technical-scientific training builds up his own autonomy and authority in research and will certainly create a positive differential for the process of teaching and learning.

\subsubsection{Pedagogical Training}

The pedagogical training is important and goes beyond teaching classes; it encompasses the whole teaching planning, including the general objectives of the subject, the students' and market knowledge, the learning evaluation, the possibilities of building up and rebuilding knowledge, as well as the teacher-student relationship. A consistent pedagogical training influential the carrying out of the professor's work because it institutes some essential didactic-pedagogical concepts and competences. One of them is to know how to involve the students in their learning and in their work developing the desire to know, the decision to learn and the ability of self-evaluation.

Gil (2006: p. 28) states that "The ability to create intellectual stimulus presents two components: the clearness in teacher's presentation and its emotional impact on students". Not only the transfer of knowledge, called clearness by the author, but also the emotional impact are related to the professor's didactics, that is, form and content depend on the professor's performance in the classroom.

The professor's difficulty on the pedagogical matter is the constant work with a diversity of interest by the student. The challenges go from the student's stimulus to the understanding of the student's lack of interest for the subject which is being taught. According to Perrenoud (2000), some students like to learn and overcome learning difficulties and obstacles while others do not. It is the professor's responsibility to create conditions, so that the learning process takes place in the most diverse aspects of the process.

In addition, besides the professor, it is necessary that the responsibility on the teaching and learning process involves the other agents of the process as well, such as the courses coordinators, other professors and the Higher Education Institution itself. Therefore, the political-pedagogical project of the course will define the professional nature of the graduates, the scope of the subjects for the training and watch out for the training of the teaching staff who will work to form this professional.

The pedagogical training helps in the understanding and domain of some sociological and didactic factors and mechanisms which influence the emergence and maintenance of the desire to know, the decision to learn and the partnership between teacher and student for learning to learn.

\subsubsection{Pedagogical Training}

The social and political training is necessary so that the teacher can make an analogy between the student and the society in a broad way, foreseeing social, political, ethical and cultural matters. The ethical and humane training of the professor make him capable of understanding and treating the differences, prejudices and discrimination of all genders with respect.

According to Andere \& Araujo (2008), the professor needs to have social training which makes him capable of engaging with other subjects of the course, as, for example, sociology, philosophy, economy, among others. It is also necessary to have political training with conditions to notice the social-cultural and political implications which take place in the national and international scope.

The professor's social and political training helps in the knowledge and reflection of the need and responsibility of conveying to the student ethical values that permeate in the society and environment where he acts. 


\section{Methodology and Result Analysis}

All these competences described before are part of the professor training and, consequently, the more complete it is, the greater the amount and quality of information he can convey to the students.

The initial training of the accounting professor is his own technical training acquired through a higher education degree. The ongoing education is the sum of this moment and the insertion of all the other knowledge he has been acquiring along the time, whether it is through technical training or business experience. "In the last years, in the discussion about ongoing training, it has been questioned the offer, by the university and other short-term (30 - 180 hours) course institutions as an actual way to alter the pedagogical practice. These courses, when they are many, offer information that, sometimes, only changes the speech of the professors and little contribute for an effective change" (Mizukami et al., 2002: p. 27).

Within this context, knowing the profile of the accounting sciences professors of the Brazilian HEI is a matter of need for a better planning of the graduation courses and then the "latosensu" and "strictosensu" 3 post graduation.

Coherently to the professor's profile, the concept of professor training is related to the permanent learning, which considers the professors' knowledge and competences as a result, not only of professional training and the teaching exercise, but also the learning carried out during life, in and out of school (Mizukami et al., 2002: p. 31). This research resumed to this discussion about the mapping and survey of aspects which direct to the accounting sciences professor's training profile in Brazil.

The work was based on the studies of education and professor training as well as on the studies of accounting education, through literature, featuring the first part of the work. In the second part, the methodology was the information gathering by questioning the accounting sciences professors of Brazil via a research questionnaire, aiming to survey the aspects and characteristics of these individuals concerning their own training as accounting professors.

The questionnaire was used as a tool of data gathering, and non-parametric methods and tests were used for the analysis of the information obtained. For the statistical treatment, the software SPSS ${ }^{\circledR}$ —Statistical Package for the Social Sciences, along with Excel, was used. This study was defined as descriptive with exploratory feature. The research questionnaire was available from April 5th, 2011 to May 31, $2011^{4}$.

As stated by Gil (2002), one of the most meaningful features of descriptive researches, along with the exploratory ones, is that they usually take the form of a survey. The objective of the research was to check the importance given by the professor of graduation courses in accounting sciences for their own training, following the areas: practical, technical-scientific, pedagogical and social and political, in the higher education professor training in Accounting in Brazil.

Thus, the research proposed to: research the subject area together with the professor of the accounting sciences courses in Brazil. The individual analysis of the training areas (practical, technical-scientific, pedagogical and social and political) was carried out.

According to Richardson (1999), the questionnaire, has the role of describing and observing features of an individual or one group of individuals, besides enabling the measurement of individual or groups variables. Moreover, the interviewee reads and interprets the questions, and answer them without any interference from the interviewer. The same model of research tool was used by Andere and Araujo (2008) and it was appropriately adjusted for this research.

The questionnaire was administered to professors divided in two steps: (i) sample featuring and(ii) information on his training as accounting professor in HEI. In stepone, the course he teaches, the professor training and his highest degree as well as the year he started teaching were identified in order to obtain the sample featuring. In step two, self assessment of the accounting professor about their training.

\subsection{Sample and Result Analysis}

The number of interviewees was 383 , however, only $80 \%$ of them answered the questionnaire in full, which came to a final total of 307 observations. After gathering the data, the tabulation was made in a spreadsheet by using the Excel-Windows program. The groups of analysis were separated in the following way.

\footnotetext{
${ }^{3}$ Latin words and they mean: "wide sense” (latosensu) and "strict sense” (strictosensu), used in Brazil for courses "specialization” and "masters-PhD”.

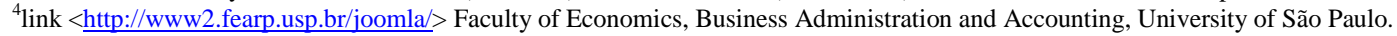




\section{Group 1: PRACTICAL TRAINING: questions 1 to 6}

1. During my hiring process as a professor, my professional experiences were decisive for being approved in the HEI.

2. I have experience as a market professional.

3. In my hiring as a professor, my practical experience was more important than the undergraduate and graduate diplomas in the specific field.

4. I hold (or held) a manager position in the market.

5. I have registration of professional certification.

6. I think it is important for the professor to be working in the market concomitant with teaching.

\section{Group 2: TECHNICAL-SCIENTIFIC TRAINING: questions 7 to 12}

7. During my hiring process as a professor, my academic knowledge and my scientific publications were important for my approval in the HEI.

8. I have technical training for the subject I teach, including master and doctorate in the field.

9. In my hiring as a professor, the undergraduate and graduate diplomas in the specific field were important.

10. I attend scientific events (national and international ones) in accounting or correlated areas.

11. I have scientific articles published in Periodicals of the field.

12. I believe it is important for the professor to be working on researches applied to accounting.

\section{Group 3: PEDAGOGICAL TRAINING: questions 13 to 18}

13. During my hiring process as a professor, my experiences in the teaching field were relevant for the approval in the HEI.

14. I have didactic courses of higher education or university teaching.

15. I have only teaching practice acquired through the learning with other professors and experience acquired in the classroom.

16. In my hiring as a professor, it was important to have didactic courses.

17. I research about accounting education methodology.

18. I believe it is important for the professor to have higher education in Didactics to work as an accounting professor.

Group 4: SOCIAL and POLITICAL TRAINING: questions 19 to 24

19. During my hiring process as a professor, my role in the social and political field was decisive for the approval in the HEI.

20. I have multidisciplinary knowledge (economy, philosophy, sociology and sciences).

21. I took part in Student Movement.

22. I did volunteer work.

23. I take part in extension activities.

24. I believe it is important for the professor to have social and political participation to work as an accounting professor.

The use of the "Likert Scale" was considered in the answers and the results were identified by the use of descriptive and cluster analyses. This analysis observed the data concerning the research on the professor training of accounting education in Brazil, specially its description, reliability, identification variable impact in the average of the answers and factorial technique, which defined the model that represents the sample researched.

\subsection{Description}

From the total of individuals, the region with the most participants is the Southeast one with 150 interviewees, followed by the South, with 74, the Northeast, with 47, the Midwest, with 26 and finally the North, with 10 . The representation was $48.9 \%$ for the Southeast region, $24.1 \%$ for the South region, $15.3 \%$ of the Northeast, $8.5 \%$ for the Midwest region and 3.3\% for the North of the country. The Figure 1 shows this distribution.

Men represented $70.49 \%$ and the others were women. The average age is 41.8 years old. The professor which answered the survey and who started his career longer ago, did it in 1970. We surveyed the ethnical information as well. From the interviewees, $78.36 \%$ are white and the Southeastern region has the majority among the participants. Among the interviewees, $63.28 \%$ are masters, $22.3 \%$ are experts, $11.48 \%$ have $\mathrm{PhD}$ and the others are graduates and post-doctors.

The reliability of the research was verified by the index known as Cronbach's Alpha, by the correlation 


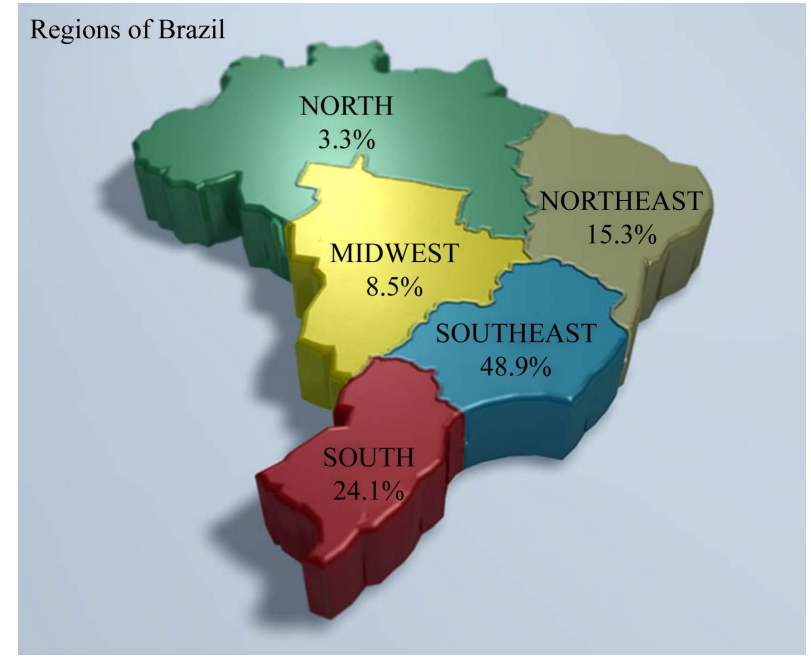

Figure 1. Regions of Brazil.

between the variables and by the covariance. This number was 0.77 . The technique presented suitability test above the average of 0.5 (KMO) explaining $66 \%$ of the sample (Table 1 ).

Cronbach's Alpha is a coefficient of internal consistency which measures the real impact of the constructs observed, having to be higher than 0.7 for this study and it was 0.77 (Pereira, 2004).

A thorough analysis of this indicator can be made by the impact the removal of one of the question in the survey and the result of this action in the index (Table 2).

Table 3 shows that the removal of almost all the questions does not increase the reliability index, only if the question were removed 15, but the increase would be 0.01 . The research presents its reliability as Cronbach's alpha was 0.77 , which is being withdrawn some issues, the indicators could reach 0.8 therefore remains reliable. The descriptive technique approaches the variations contained in the answers of the sample and evidence the trend of the interviewees and the scale used was from " 1 " I completely disagree to " 5 " I completely agree.

The questions which stand out with I COMPLETELY AGREE are the performance in the pedagogical training and in the social and political area, representing: (i) $27.5 \%$ in question 15 "I have only teaching practice acquired through the learning with other professors and experience acquired in the classroom. "Group 3: PEDAGOGICAL TRAINING; (ii) 38.7\% in question 19 "During my hiring process as a professor, my role in the social and political field was decisive for the approval in the HEI" Group 4: SOCIAL and POLITICAL TRAINING, and (iii) $49.8 \%$ in question 21 "I took part in Student Movement" Group 4: SOCIAL and POLITICAL TRAINING.

The second part of the descriptive analysis observes the impact of the identification variables in the average answers of the sub-samples. For analysis of the place effect, it was proposed the separation of the interviewees in the five regions of Brazil: north, northeast, central-west, southeast and south. Based on the average of the answers, the central-western region is the one that presents the most adherence and the southern region the one with the least.

The measurement of the degree effect happened through the information of the highest degree of the interviewees. The most adherent average answers to the research were in the $\mathrm{PhD}$ category and the least adherent ones of post-doctorates, which represents, in a certain way, a low number of interviewees.

The use of factorial technique aimed to analyze whether the variables (questions) can be grouped, so that it is possible to identify what professor training prevails in the characterization of this sample.

Two rounds were carried out, since from this point on, the technique does not present satisfactory results. The technique presented suitability test higher than the minimum of $0.5 \%$, with an explanatory power of $66 \%$. In both rounds, the model presents suitability, since the KMO was higher than 0.5 (Table 4). The use of the factorial technique involved the twenty-four questions (variables) contained in the second part of the questionnaire and its objective was to raise the professor training of the accounting sciences courses in Brazil. Thus, this analysis involved two suitability tests, the observation of the anti-image correlation matrix and the commonalities. 
Table 1. Cronbach’s Alpha.

\begin{tabular}{ccc}
\hline & \multicolumn{2}{c}{ Reliability Statistics } \\
\hline Cronbach's Alpha & Cronbach's Alpha Based on Standardized Items & N of Items \\
\hline 0.776193349 & 0.792796638 & 24 \\
\hline
\end{tabular}

Source: research data, base in Statistical Package for the Social Sciences (SPSS).

Table 2. Cronbach’s Alpha.

\begin{tabular}{|c|c|c|c|c|c|}
\hline \multirow[b]{2}{*}{ Questions } & \multicolumn{5}{|c|}{ Item-Total Statistics } \\
\hline & $\begin{array}{c}\text { Scale Mean if Item } \\
\text { Deleted }\end{array}$ & $\begin{array}{l}\text { Scale Variance if } \\
\text { Item Deleted }\end{array}$ & $\begin{array}{l}\text { Corrected Item-Total } \\
\text { Correlation }\end{array}$ & $\begin{array}{l}\text { Squared Multiple } \\
\text { Correlation }\end{array}$ & $\begin{array}{l}\text { Cronbach's Alpha if } \\
\text { Item Deleted }\end{array}$ \\
\hline 1 & 58.23 & 161.29 & 0.53 & 0.55 & 0.76 \\
\hline 2 & 58.40 & 163.39 & 0.47 & 0.57 & 0.76 \\
\hline 3 & 57.30 & 175.77 & 0.09 & 0.35 & 0.78 \\
\hline 4 & 57.90 & 170.93 & 0.17 & 0.32 & 0.78 \\
\hline 5 & 58.60 & 165.61 & 0.34 & 0.28 & 0.77 \\
\hline 6 & 58.39 & 165.18 & 0.46 & 0.45 & 0.76 \\
\hline 7 & 57.96 & 163.74 & 0.45 & 0.47 & 0.76 \\
\hline 8 & 57.91 & 168.12 & 0.30 & 0.30 & 0.77 \\
\hline 9 & 58.50 & 163.07 & 0.54 & 0.53 & 0.76 \\
\hline 10 & 58.11 & 164.47 & 0.45 & 0.50 & 0.76 \\
\hline 11 & 57.72 & 170.07 & 0.21 & 0.46 & 0.78 \\
\hline 12 & 58.50 & 159.95 & 0.63 & 0.67 & 0.75 \\
\hline 13 & 58.05 & 162.50 & 0.50 & 0.43 & 0.76 \\
\hline 14 & 57.82 & 165.53 & 0.31 & 0.58 & 0.77 \\
\hline 15 & 57.26 & 189.56 & -0.26 & 0.48 & 0.80 \\
\hline 16 & 56.93 & 172.30 & 0.19 & 0.44 & 0.78 \\
\hline 17 & 57.62 & 166.38 & 0.35 & 0.22 & 0.77 \\
\hline 18 & 58.29 & 162.02 & 0.53 & 0.52 & 0.76 \\
\hline 19 & 56.73 & 174.50 & 0.13 & 0.44 & 0.78 \\
\hline 20 & 57.86 & 166.89 & 0.39 & 0.21 & 0.76 \\
\hline 21 & 56.74 & 178.74 & -0.01 & 0.23 & 0.79 \\
\hline 22 & 57.59 & 166.21 & 0.31 & 0.25 & 0.77 \\
\hline 23 & 58.09 & 164.38 & 0.44 & 0.29 & 0.76 \\
\hline 24 & 57.85 & 165.76 & 0.40 & 0.42 & 0.76 \\
\hline
\end{tabular}

Source: research data.

Table 3. Desciptive technique.

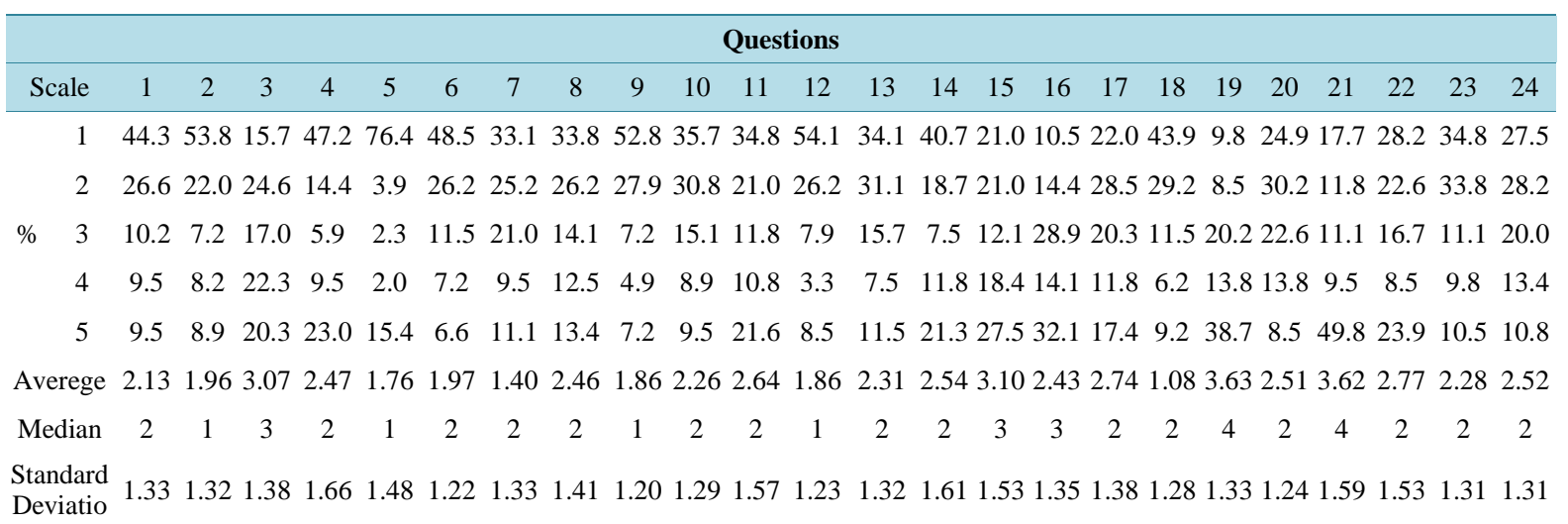

Source: research data. 
Table 4. Adequacy test.

\begin{tabular}{cccc}
\hline & Adequacy Test & & Second Round \\
\hline & & First Round & 0.64 \\
KMO & & 0.82 & 914.97 \\
Bartlett's Test of Sphericity & Approx. Chi-Square & 2491.02 & 55.00 \\
& df & 276.00 & 0.00 \\
\hline
\end{tabular}

Source: research data.

The first round of factorial analysis involved the Kaiser-Meyer-Olkin, the sphericity test and the observation of the anti-image correlation matrix. The variables which present results lower than 0.5 were taken out of the model because they did not present the minimum correlation required for use in this multivariate analysis. The Table 5 shows this analysis.

In the second round of the factorial analysis (Table 6), involving the same methodology, the questions which remained were: $02,13,14$ and 15 since they presented result higher than 0.5 .

After the verification of the variable commonalities, and since all of them have value equal to or above 0.7, the next step is the verification of the explanatory degree obtained by the factorial analysis. The factorial technique has the explanatory power of $66.5 \%$ and presents 4 factors and 4 variables (Table 7).

Factor 2 involves the professor's pedagogical training. Question 14 "I have didactic courses of higher education or university teaching" represents this factor. In the sequence, factor 1 is represented by question 13 "During my hiring process as a professor, my experiences in the teaching field were relevant for the approval in the HEI". Factors 1 and 2 belong to group 3, PEDAGOGICAL TRAINING. Factor 3 is represented by question 2 "I have experience as a market professional". This question represents the PRACTICAL TRAINING. Finally, factor 4, represents question 15 "I have only teaching practice acquired through the learning with other professors and experience acquired in the classroom". This factor also belongs to the PEDAGOGICAL TRAINING group.

\section{Conclusion}

The importance of the professor in the training of any individual is unquestionable. Besides conveying knowledge, the professor must also have didactic conditions so that this transmission is positive and the learning and teaching process is concluded.

The accounting sciences courses in Brazil grew in an expressive way in the last years. Accounting offers several professional working areas, not only in the private but also in the public enterprise. Some of these activities can be highlighted: accountant, auditor, professional working in the money and financial markets, legal advice provider, tax auditor, professor, among others. Furthermore, it embraces besides the accounting training, other fields of knowledge, such as business administration, economy, law and engineering.

The teaching career for the accounting field is one of the options for the undergraduate. However, to enter higher education, it will be necessary of the deepening in knowledge and researches, besides the "strictosensu" course. In this context, the proposal of the study was to analyze the higher education professor training in accounting sciences in Brazil, by using the model of Vasconcelos (1994). The model foresees the professor training in four groups: (i) practical training; (ii) technical training; (iii) pedagogical training and; (iv) social and political training.

After the gathering of the professors' perceptions of accounting sciences in Brazil through online questionnaire from April 5th to May 31, 2011, the total of interviewees was of 383 and the use for the research was of 305 answers. When applying the factorial analysis in the 24 variables, corresponding to 24 questions of the questionnaire, the objective was to find a smaller number of factors which could explain the variation of the object of study. After two rounds of analyses, we came up to 4 factors which are linked to the 4 questions of the study. They are: questions 2, 13, 14 and 15.

Three of these questions (13, 14 e 15) belong to the group called Pedagogical training. According to the answers analyzed, most part (above 50\% in all of them) said that these factors were not important during their hiring process, or that they do not have knowledge of didactics and that somehow it did not influential in their hiring in the Education Institution. Therefore, we can conclude, for this universe, that the pedagogical training is lower than other pre-determinate groups in the research. 
Table 5. Factory analysis-first round.

\begin{tabular}{|c|c|c|}
\hline Question & Initial & Extraction \\
\hline 1 & 1 & 0.67 \\
\hline 2 & 1 & 0.72 \\
\hline 3 & 1 & 0.74 \\
\hline 4 & 1 & 0.78 \\
\hline 5 & 1 & 0.44 \\
\hline 6 & 1 & 0.58 \\
\hline 7 & 1 & 0.70 \\
\hline 8 & 1 & 0.50 \\
\hline 9 & 1 & 0.64 \\
\hline 10 & 1 & 0.70 \\
\hline 11 & 1 & 0.75 \\
\hline 12 & 1 & 0.76 \\
\hline 13 & 1 & 0.70 \\
\hline 14 & 1 & 0.80 \\
\hline 15 & 1 & 0.76 \\
\hline 16 & 1 & 0.72 \\
\hline 17 & 1 & 0.42 \\
\hline 18 & 1 & 0.66 \\
\hline 19 & 1 & 0.65 \\
\hline 20 & 1 & 0.55 \\
\hline 21 & 1 & 0.57 \\
\hline 22 & 1 & 0.49 \\
\hline 23 & 1 & 0.44 \\
\hline 24 & 1 & 0.66 \\
\hline
\end{tabular}

Source: research data.

Table 6. Factory analysis—second round.

\begin{tabular}{ccc}
\hline Question & Initial & Extraction \\
\hline $\mathbf{2}$ & $\mathbf{2}$ & $\mathbf{0 . 7 5}$ \\
3 & 2 & 0.60 \\
4 & 2 & 0.56 \\
7 & 2 & 0.66 \\
10 & 2 & 0.62 \\
11 & 2 & 0.43 \\
12 & 2 & 0.67 \\
$\mathbf{1 3}$ & $\mathbf{2}$ & $\mathbf{0 . 7 0}$ \\
$\mathbf{1 4}$ & $\mathbf{2}$ & $\mathbf{0 . 8 3}$ \\
$\mathbf{1 5}$ & $\mathbf{2}$ & $\mathbf{0 . 8 3}$ \\
16 & 2 & 0.68 \\
\hline
\end{tabular}

Source: research data. 
Table 7. Combination of factors-groups.

\begin{tabular}{ccccc}
\hline Questions & Factor 1 & Factor 2 & Factor 3 & Factor 4 \\
\hline 2 & 0.51 & 0.22 & 0.65 & -0.14 \\
3 & -0.09 & 0.41 & 0.55 & 0.34 \\
4 & 0.14 & 0.27 & 0.64 & -0.18 \\
7 & 0.69 & -0.32 & -0.07 & 0.28 \\
10 & 0.70 & -0.32 & 0.08 & -0.14 \\
11 & 0.52 & -0.34 & -0.19 & -0.07 \\
12 & 0.79 & -0.15 & 0.12 & -0.11 \\
13 & 0.63 & 0.03 & -0.12 & 0.53 \\
14 & 0.49 & 0.66 & -0.33 & -0.20 \\
15 & -0.34 & -0.65 & 0.37 & -0.20 \\
\hline
\end{tabular}

Source: research data.

Other factors indicate that the average in the sample training is between expert-master. The average age of the interviewees is of 41.8 years old. This factor can represent an Academy removal or, even, if we observe the number of PhDs, the training may not be enough for the high level professor's practice; in case the assumption is the quality of education which is related to the professor's degree.

For the sample analysis, the practical training is the most explained one among the researched ones, representing $66 \%$ of the variables. The link between theory and practice is many times required by the student and indispensable for his professional training and in this sample, it is proved that the accounting sciences professor in Brazil has this training. In the second aspect of the training, there is the technical-scientific area, in the third the social-political and in fourth and last, the pedagogical one. We have seen that for this study, the professor who works in the teaching of accounting sciences in Brazil does not have pedagogical training. "Reflecting on your own ways of learning and teaching is considered a key-element in the 'learn to learn' and 'learn to teach' processes. The knowledge of practice, as well as the theoretical knowledge, is not ready and over” (Mizukami et al., 2002: p. 167).

For future studies, it is understood that the increase of the observation basis is necessary and timely. Carrying out a study on pedagogical projects of the courses can also complete information of researches for the analysis of professional training by the HEI. The use of the research to the professors, observing a greater number of answers and a possible crossing with the professional training the professor is working on will be of extreme relevance for the accounting field in Brazil, including better targeting of educational policies.

A possible continuity of the research can be performed through the deepening in qualitative data seen in the research. With the database and the answers received, future researches can use the interviews directed to the professors of all the regions of the country and enhance to other courses, such as, for example, Business Administration and Economy.

Another aspect the research points is the comparison to the international scenario, more specifically, with higher education institutions of excellence, whether in the United States of America or in the European continent for future research cooperation and experiences on the theme.

\section{Acknowledgements}

I thank the State of São Paulo Research Foundation (FAPESP), Brazil, for supporting the research and the Federal University of São Carlos (UFSCar), Department of Pedagogical Theories and Practices under the supervision of PhD ProfessorRoseli Rodrigues de Mello.

\section{References}

Andere, M. A. (2007). Aspectos da Formação do Professor de Ensino Superior de Ciências Contábeis: Umaanálise dos Programas de Pós-graduação. Dissertation (Masters in Controlling and Accounting), São Paulo: Universidade de São Paulo, Faculdade de Economia, Administração e Contabilidade de Ribeirão Preto. 
Andere, M. A., \& Araujo, A. M. P. de (2008). Aspectos da formação do professor de ensino superior de ciênciascontábeis: Umaanálise dos programas de pós-graduação. Revista Contabilidade \& Finanças (Printed), 19, 91-102.

http://dx.doi.org/10.1590/S1519-70772008000300008

Cornachione Jr., E. B. (2004). Tecnologia da educação e cursos de ciênciascontábeis: Modeloscolaborativosvirtuais. Thesis (Free-Docency), São Paulo: Faculdade de Economia, Administração e Contabilidade, USP.

Cunha, M. I. (1996) O bom professor e suaprática (6th ed.). Campinas: Papirus Editora.

Delors, J. (1996). Educação, um tesouro a descobrir. Relatório para a UNESCO da Comissãointernacionalsobre Educação para o século XXI. (Original Title: Learning: The Treasure within; Report to UNESCO of the International Commission on Education for the Twenty-first Century (highlights)). Paris: UNESCO (Published by the Setor de Educação da Representação of UNESCO in Brasil, Sponsored by FundaçãoFaberCastell, Traslation: GuilhermeJoão de Freitas Teixeira) http://unesdoc.unesco.org/images/0010/001095/109590por.pdf

Delors, J. (1999) Um Tesouro a Descobrir. São Paulo: UNESCO, MEC, Cortez Editora.

Feltran. R. C. S. (2002). Avaliaçãonaeducação superior. Campinas: Papirus Editora.

Gil, A.C. (2002). Como elaborarprojetos de pesquisa (4th ed.). São Paulo: Editora Atlas.

Gil, A. C. (2006). Didática do ensino superior. São Paulo: Editora Atlas.

Gómez, A. P. (1992). O pensamento prático do professor: A formação do professor como profissional reflexivo. In A. Nóvoa (Coord.), Osprofessores e a suaformação. Lisboa: Publicações Dom Quixote.

Guerra, C. T. (2003). O ensino de psicologianaformaçãoinicial de professores: Constituição de conhecimentossobreaprendizagem e desenvolvimentoporestudantes de licenciatura. Thesis (Education Doctorate), Campinas: Faculdade de Educação, Universidade Estadual de Campinas.

Hernandes, D. C. R., et al. (2006). O professor de contabilidade: habilidades e competências. In I. R. Peleias (Org.), Didática do ensino superior da contabilidade: Aplicávela outros cursossuperiores (pp. 61-119). São Paulo: Saraiva.

Laffin, M. (2002). De contador a professor: A trajetória da docência no ensino superior de contabilidade. Thesis (Doctorate in Production Engineering), Florianópolis: Universidade Federal de Santa Catarina.

Marion, J. C. (1993). Aspectos do ensino da contabilidadenos Estados Unidos. São Paulo: Fipecafi/FEA-USP, Caderno de Estudos, n.7.

Martins, A. C. P. (2005). Ensino superior no Brasil: Da descobertaaosdiasatuais. Acta Cirúrgica Brasileira, 17, 4-6.

Meier, A. (2004). Contribuição para melhoriaqualitativa do corpodocentenoscursos de graduação de umainstituição de ensino superior de Curitiba-Paraná. Dissertation (másters in Production Engineering), Florianópolis: Universidade Federal de Santa Catarina.

Mello, R. R. de (1998). Os saberes docentes e a formação cotidiana nas series iniciais do ensino fundamental: Um estudo de casosmúltiplos de tipo etnográfico. PhD Thesis, São Carlos: Universidade Federal de São Carlos, Programa de Pós-Graduação em Educação.

Mizukami, M. G. N., et al. (2002). Escola e aprendizagem da docência: Processos de investigação e formação. São Carlos: EDUFSCAR.

Nossa, V. (1999). Ensino da contabilidade no Brasil: Umaanálisecrítica da formação do corpodocente. Dissertação (MestradoemCiências Contábeis), São Paulo: Faculdade de Economia, Administração e Contabilidade, Universidade de São Paulo.

Nunes, C. S. C. (2000). Ossentidos da formaçãocontínua de professores: O mundo do trabalho e a formação de professores no Brasil. Thesis (PhD in Education). Campinas: Faculdade de Educação, Universidade Estadual de Campinas.

Pachane, G. G. (2003). Aimportância da formaçãopedagógica para o professor universitário: A experiência da UNICAMP. Thesis (PhD in Education. Concentration Field), Faculdade de Educação, Campinas: Universidade Estadual de Campinas.

Pereira, J. C. R. (2004). Análise de dados qualitativos: Estratégias metodológicas para as ciências da saúde, humanas e sociais (3rd ed.). São Paulo: Editora da Universidade de São Paulo.

Perrenoud, P. (2000). Dez novas competências para ensinar. Porto Alegre: Artes MédicasSul.

Richardson, R. J. (1999). Pesquisa Social: métodos e técnicas (3rd ed.). São Paulo: Atlas.

Vasconcelos, M. L. M. C. (1994). O profissional liberal na docência de $3^{\circ}$ grau: Uma proposta de atualização pedagógica. Thesis (PhD in Business Administration), São Paulo: Universidade Mackenzie.

Vasconelos, M. L. M. C. (2000). A formação do professor do ensino superior (2nd ed.). São Paulo: Pioneira.

Veiga, I. P. A. (2003). Inovações e projetopolítico-pedagógico: Uma relação regulatória ou emancipatória? UNICAMP, Campinas, Caderno CEDES, 23, 267-281. http://www.cedes.unicamp.br 
Scientific Research Publishing (SCIRP) is one of the largest Open Access journal publishers. It is currently publishing more than 200 open access, online, peer-reviewed journals covering a wide range of academic disciplines. SCIRP serves the worldwide academic communities and contributes to the progress and application of science with its publication.

Other selected journals from SCIRP are listed as below. Submit your manuscript to us via either submit@scirp.org or Online Submission Portal.
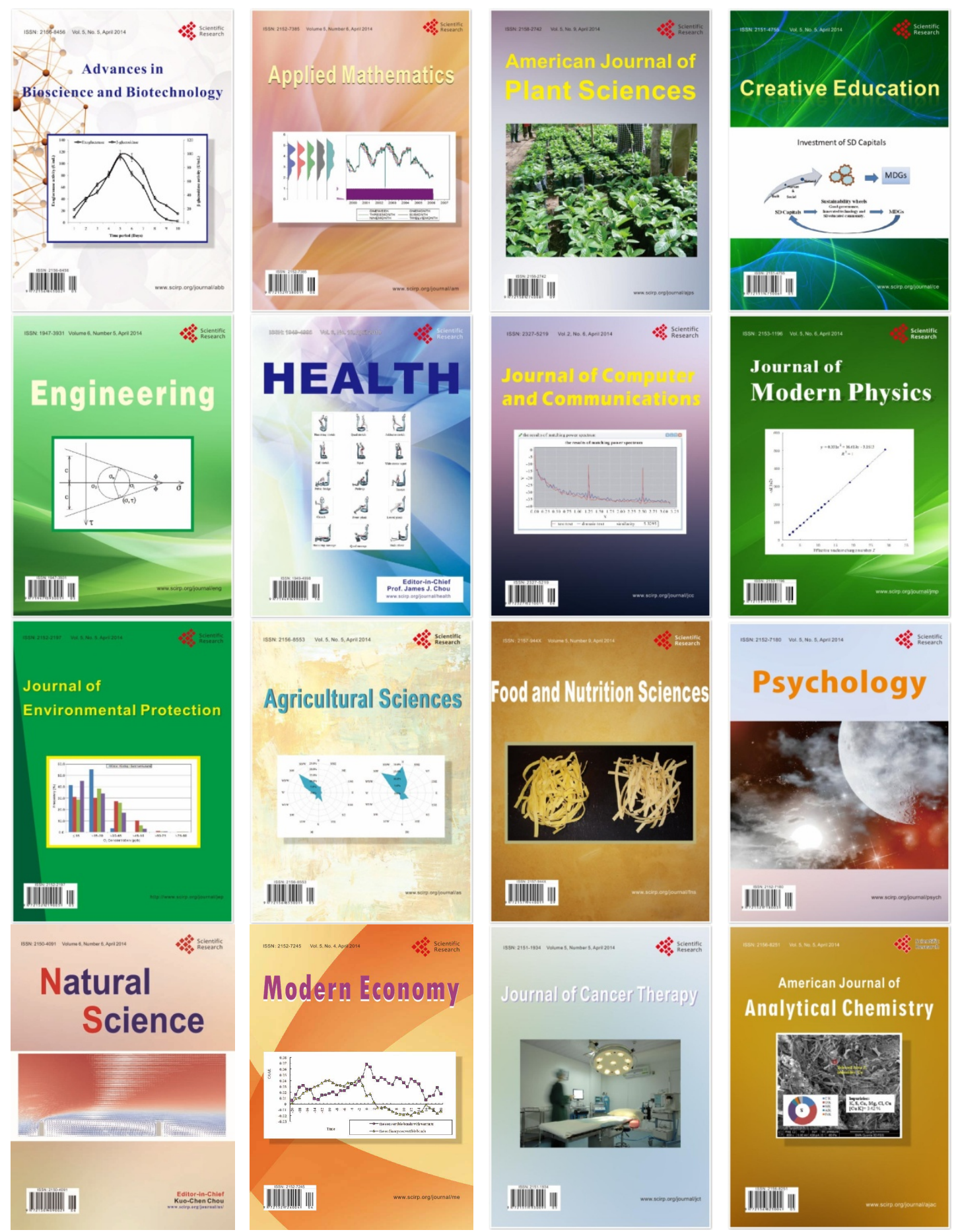